\title{
Comparison of two multiplex PCR assays for the detection of Listeria spp. and Listeria monocytogenes in biological samples
}

\author{
Sylwia Budniak, Agnieszka Kędrak-Jabłońska, Anna Szczawińska, \\ Monika Reksa, Marek Krupa, Krzysztof Szulowski \\ Department of Microbiology, National Veterinary Research Institute, 24-100 Pulawy, Poland \\ sylwia.budniak@piwet.pulawy.pl
}

Received: August 1, $2016 \quad$ Accepted: November 23, 2016

\begin{abstract}
Introduction: The aim of the study was to optimise and compare two multiplex PCR assays for the detection of Listeria spp. and Listeria monocytogenes in biological samples including the liver, brain, and blood. Material and Methods: Three strains of L. monocytogenes and single strains of each of the species: L. ivanovii, L. innocua, L. grayi, L. welshimeri, and L. seeligeri were used. Additionally, five other species of bacterium were used to evaluate the specificity of the tests. Results: Specific amplification products were obtained for both multiplex PCR assays, which confirmed the tested strains as Listeria spp. and L. monocytogenes, respectively. Isolates of other species did not yield PCR products. Conclusion: Both multiplex PCR assays proved to be significantly sensitive and highly-specific methods for the detection of Listeria strains.
\end{abstract}

Keywords: Listeria, listeriosis, biological samples, PCR.

\section{Introduction}

Listeria monocytogenes is widely distributed in the natural environment. This organism can cause infections both in humans and animals. In humans, the elderly, the chronically ill, people with an impaired immune system, pregnant women, and newborns are most vulnerable to infection with $L$. monocytogenes. In pregnant women it induces flu-like symptoms and is associated with spontaneous abortions. In newborns listeriosis takes the form of granulomatosis infantiseptica, the mortality rate of which can reach $100 \%$. Clinically, the disease occurs most often in the form of encephalitis and meningitis. Other forms of listeriosis in humans include skin lesions, conjunctivitis, lymphadenitis, endocarditis, osteomyelitis, pneumonia, and gastroenteritis $(5,14,24,25)$.

In animals, the symptoms of the disease depend on the age and physiological condition of the affected specimen. Listeriosis can affect the central nervous system, the reproductive system, internal organs, or can take the form of septicaemia. Listeriosis in the reproductive system leads to spontaneous abortion. The majority of clinical cases of the disease are noted in sheep, goats, and cattle, whereas in horses, pigs, cats, dogs, and fowls they occur very rarely. Among fur animals, chinchillas are particularly sensitive to this disease $(12,18,20)$.

Bacteriological examination is the "gold standard" in the isolation and identification of L. monocytogenes from biological material. The laboratory identification of the microorganism is based on the culture on selective enrichment broths and selective agars, and then on the evaluation of colony morphology, and physiological and biochemical properties of the isolate. The examination is time-consuming and requires specialised tests (9).

Genotyping methods for the identification of bacteria are free of constraints that exist in traditional phenotype techniques. The tests based on the analysis of nucleic acids allow a direct detection of microorganisms in bacterial cultures or clinical samples. These tests increase the sensitivity of the method and reduce the time of identification. PCR with primers designed to identify microorganisms at the strain, species, or genus level is considered particularly useful. The method is used for rapid and sensitive detection of L. monocytogenes (19, 26, 27).

The aim of this study was to optimise and compare two selected multiplex PCR assays enabling 
the simultaneous detection of Listeria genus and species of L. monocytogenes in experimentally contaminated biological samples (bovine liver, brain, and blood).

\section{Material and Methods}

Bacterial strains. The study involved three reference strains of Listeria monocytogenes: L. monocytogenes ATCC 7644, L. monocytogenes ATCC 13932, and L. monocytogenes ATCC 19112. To assess the specificity of the tests, strains of other species of the Listeria genus, including single strains of L. ivanovii ATCC 19119, L. innocua ATCC 33090, L. grayi ATCC 19120, L. welshimeri ATCC 35897, and L. seeligeri originating from the collection of the Department of Microbiology, National Veterinary Research Institute in Pulawy, Poland, were used. In addition, the experiments involved strains of other species, including Bacillus cereus ATCC 11778, Staphylococcus aureus ATCC 6538, Escherichia coli ATCC 25922, Salmonella Typhimurium ATCC 14028, and Klebsiella pneumoniae ATCC 13883.

Isolation of DNA. Each strain was streaked onto TSYEA medium. Cultures were incubated for $24 \mathrm{~h}$ at $37^{\circ} \mathrm{C}$ and then a bacterial suspension with a density of 1 McFarland Standard was prepared. Samples of $1 \mathrm{~mL}$ were centrifuged for $10 \mathrm{~min}$ at $13,000 \mathrm{rpm}$. The supernatant was removed and the pellet was used to contaminate the liver, brain, and blood. To isolate DNA a DNeasy Blood and Tissue Kit (Qiagen, USA) was used.

The sensitivity of the PCRs was determined by a 10-fold dilution technique. The initial concentration of L. monocytogenes ATCC 13932 was about $1.5 \times 10^{6}$ CFU/reaction.

Primers. Sequences of primers for amplification were based on the literature data, for the first multiplex
PCR assay in accordance with Chen and Knabel (2), and for the second one according to Doumith et al. (4) and Gouws and Liedemann (11). The primers were synthesised in the Laboratory of DNA Sequencing and Oligonucleotide Synthesis, IBB PAN (Poland). The characteristics of the PCR primers are shown in Tables 1 and 2.

PCR assays. In both multiplex PCR assays two different reaction mixtures were used. The first contained $200 \mu \mathrm{M}$ of each deoxynucleotide triphosphate (dNTP) (Thermo Scientific, USA), $1 \times$ PCR buffer containing $2 \mathrm{mM}$ of $\mathrm{MgCl}_{2}$, and $1 \mathrm{U}$ of DNA polymerase (Biotools, Spain). The second was the QIAGEN Multiplex PCR Kit reaction mixture containing $3 \mathrm{mM}$ of $\mathrm{MgCl}_{2}$ (Qiagen, USA). PCR assays were performed in a $25 \mu \mathrm{L}$ reaction mixture volume containing $5 \mu \mathrm{L}$ of the DNA and a defined amount of each primer. Primer concentrations $(0.01 \mu \mathrm{M}, 0.03 \mu \mathrm{M}$, $0.05 \mu \mathrm{M}, 0.10 \mu \mathrm{M}, 0.20 \mu \mathrm{M}, 0.50 \mu \mathrm{M}, 1.00 \mu \mathrm{M}$, and $1.50 \mu \mathrm{M})$ were evaluated to optimise the reactions.

PCR assays were performed in a TProfessional Basic Thermocycler (Biometra, Germany) using the following parameters: initial denaturation at $95^{\circ} \mathrm{C}$ for $15 \mathrm{~min}$, followed by 15 cycles of $94^{\circ} \mathrm{C}$ for $90 \mathrm{~s}$, 3 cycles from $55^{\circ} \mathrm{C}$ to $51^{\circ} \mathrm{C}$ per temperature for $90 \mathrm{~s}$, $72^{\circ} \mathrm{C}$ for $90 \mathrm{~s}, 15$ cycles of $94^{\circ} \mathrm{C}$ for $90 \mathrm{~s}, 50^{\circ} \mathrm{C}$ for $90 \mathrm{~s}$, $72^{\circ} \mathrm{C}$ for $90 \mathrm{~s}$, and a final elongation step at $72^{\circ} \mathrm{C}$ for 8 $\min$.

Electrophoretic separation of the amplification products was performed on a $2 \%$ agarose gel in TBE buffer at a constant voltage of $95 \mathrm{~V}$, in the Wide MiniGT Sub Cell apparatus (Bio-Rad, USA). The $100 \mathrm{bp}$ Plus DNA Ladder (Thermo Scientific, USA) was used as a molecular weight marker. After electrophoresis, the gels were stained with ethidium bromide and photographed using the Vilber Lourmat (Germany) recording system.

Table 1. The characteristics of the primers for multiplex PCR according to Chen and Knabel (2)

\begin{tabular}{|c|c|c|c|c|}
\hline \multirow[b]{2}{*}{ Gene target } & \multirow[b]{2}{*}{ Primer sequence $\left(5^{\prime}-3^{\prime}\right)$} & \multirow[b]{2}{*}{ Product size } & \multicolumn{2}{|c|}{ Concentration } \\
\hline & & & $\begin{array}{l}\text { Reaction mixture containing } \\
2 \mathrm{mM} \text { of } \mathrm{MgCl}_{2}\end{array}$ & $\begin{array}{c}\text { Qiagen reaction mixture } \\
\text { containing } \\
3 \mathrm{mM} \text { of } \mathrm{MgCl}_{2}\end{array}$ \\
\hline \multirow{2}{*}{ iap } & (F) ATGAATATGAAAAAAGCAAC & \multirow{2}{*}{$1450-1600$ bp } & \multirow{2}{*}{$0.10 \mu \mathrm{M}$} & \multirow{2}{*}{$0.20 \mu \mathrm{M}$} \\
\hline & (R) TTATACGCGACCGAAGCCAAC & & & \\
\hline \multirow[t]{2}{*}{$\operatorname{lmo} 2234$} & (F) TGTCCAGTTCCATTTTTAACT & \multirow{2}{*}{$420 \mathrm{bp}$} & \multirow{2}{*}{$0.03 \mu \mathrm{M}$} & \multirow{2}{*}{$0.05 \mu \mathrm{M}$} \\
\hline & (R) TTGTTGTTCTGCTGTACGA & & & \\
\hline
\end{tabular}

Table 2. The characteristics of the primers for multiplex PCR according to Doumith et al. (4) and Gouws and Liedemann (11)

\begin{tabular}{|c|c|c|c|c|}
\hline \multirow[b]{2}{*}{ Gene target } & \multirow[b]{2}{*}{ Primer sequence $\left(5^{\prime}-3^{\prime}\right)$} & \multirow[b]{2}{*}{ Product size } & \multicolumn{2}{|c|}{ Concentration } \\
\hline & & & $\begin{array}{l}\text { Reaction mixture containing } \\
\qquad 2 \mathrm{mM} \text { of } \mathrm{MgCl}_{2}\end{array}$ & $\begin{array}{c}\text { Qiagen reaction mixture } \\
\text { containing } \\
3 \mathrm{mM} \text { of } \mathrm{MgCl}_{2} \\
\end{array}$ \\
\hline \multirow{2}{*}{ prs } & (F) GCTGAAGAGATTGCGAAAGAAG & \multirow{2}{*}{370 bp } & \multirow{2}{*}{$0.20 \mu \mathrm{M}$} & \multirow{2}{*}{$0.20 \mu \mathrm{M}$} \\
\hline & (R) CAAAGAAACCTTGGATTTGCGG & & & \\
\hline \multirow{2}{*}{ hly } & (A)CATTAGTGGAAAGATGGAATG & \multirow{2}{*}{$730 \mathrm{bp}$} & \multirow{2}{*}{$0.50 \mu \mathrm{M}$} & \multirow{2}{*}{$0.50 \mu \mathrm{M}$} \\
\hline & (B)GTATCCTCCAGAGTGATCGA & & & \\
\hline
\end{tabular}




\section{Results}

In the first stage, a multiplex PCR was performed using the iap and lmo2234 genes (Table 1) with the template DNA obtained from biological samples contaminated experimentally with L. monocytogenes. The iap gene allowed the confirmation of the strains as Listeria spp., and the lmo2234 gene served for confirmation as L. monocytogenes species. In the case of these genes, fragments of 1450-1600 bp and $420 \mathrm{bp}$ were obtained. The first stage focused on the influence of different primer concentrations with the use of two reaction mixtures. The optimal concentrations of primers for the reaction mixture containing $2 \mathrm{mM}$ of $\mathrm{MgCl}_{2}$ were $0.10 \mu \mathrm{M}$ for the iap gene and $0.03 \mu \mathrm{M}$ for the 1 mo2234 gene. Using the reaction mixture containing $3 \mathrm{mM}$ of $\mathrm{MgCl}_{2}$ the optimal concentrations were $0.20 \mu \mathrm{M}$ and $0.05 \mu \mathrm{M}$, respectively. The amplified fragments were clearly seen in assays on the liver, brain, and blood samples contaminated with the tested strains of L. monocytogenes, with both the

a)

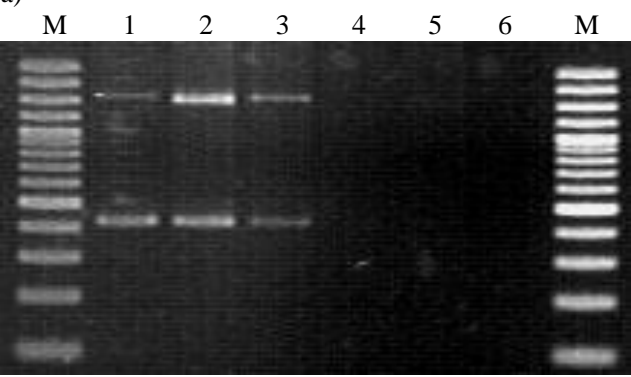

b)

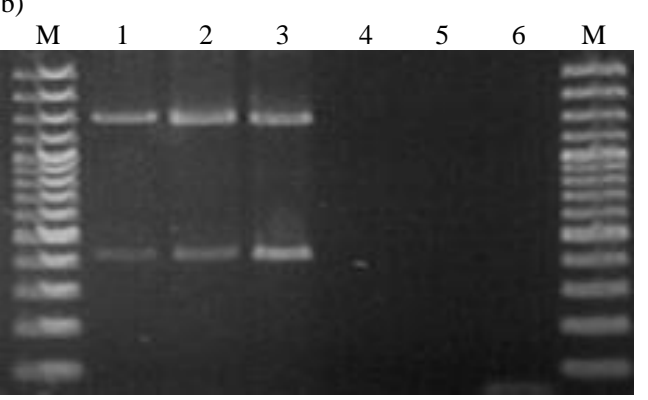

c)

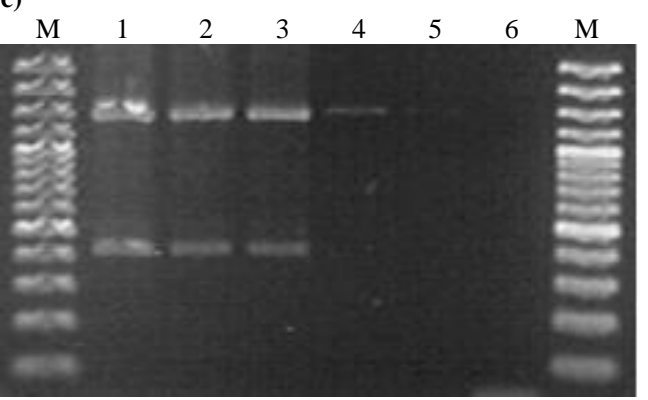

Fig. 1. Determination of the sensitivity of a multiplex PCR according to Chen and Knabel (2) using the reaction mixture containing $2 \mathrm{mM}$ of $\mathrm{MgCl}_{2}$ for the detection of L. monocytogenes ATCC 13932 strain in the liver (a), brain (b), and blood (c): $1.5 \times 10^{6} \mathrm{CFU} /$ reaction (1), $1.5 \times 10^{5}$ CFU/reaction (2), $1.5 \times 10^{4} \mathrm{CFU} /$ reaction (3), $1.5 \times 10^{3}$ CFU/reaction (4), $1.5 \times 10^{2} \mathrm{CFU} /$ reaction (5), negative control (6), and molecular weight marker (M) reaction mixture containing $2 \mathrm{mM}$ of $\mathrm{MgCl}_{2}$ and the reaction mixture containing $3 \mathrm{mM}$ of $\mathrm{MgCl}_{2}$.

Then the sensitivity of this PCR was evaluated. The examination of the DNA from contaminated liver, brain, and blood samples revealed the same sensitivity of $1.5 \times 10^{4} \mathrm{CFU} /$ reaction for both reaction mixtures (Fig. 1).

In the next step, the amplification was performed using the prs and hly genes (Table 2). Confirmation of the strains as Listeria spp. was possible by detecting the prs gene, whereas detecting the hly gene allowed the identification of L. monocytogenes species. In the case of these genes, products of $370 \mathrm{bp}$ and $730 \mathrm{bp}$ were obtained, respectively. The optimum primer concentration was $0.2 \mu \mathrm{M}$ for the prs gene and $0.5 \mu \mathrm{M}$ for the hly gene in both the reaction mixture with $2 \mathrm{mM}$ and the mixture with $3 \mathrm{mM}$ of $\mathrm{MgCl}_{2}$. Both reaction mixtures allowed to detect the presence of the amplified fragments found in the liver, brain, and blood samples contaminated with the tested L. monocytogenes strains.

a)

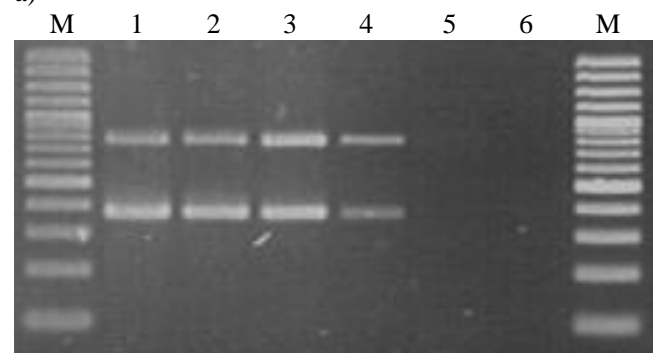

b)

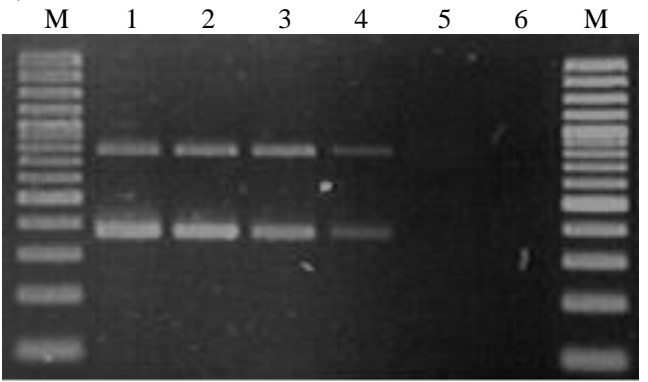

c)

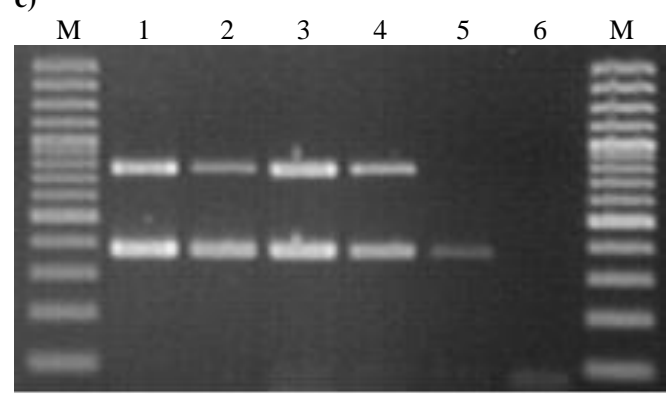

Fig. 2. Determination of the sensitivity of multiplex PCR according Doumith et al. (4) and Gouws and Liedemann (11) using the reaction mixture containing $3 \mathrm{mM}$ of $\mathrm{MgCl}_{2}$ for the detection of L. monocytogenes ATCC 13932 strain in the liver (a), brain (b), and blood (c): $1.5 \times 10^{6}$ CFU/reaction (1), $1.5 \times 10^{5} \mathrm{CFU} /$ reaction (2), $1.5 \times 10^{4}$ CFU/reaction (3), $1.5 \times 10^{3} \mathrm{CFU} /$ reaction (4), $1.5 \times 10^{2}$ CFU/reaction (5), negative control (6), and molecular weight marker (M) 
a)

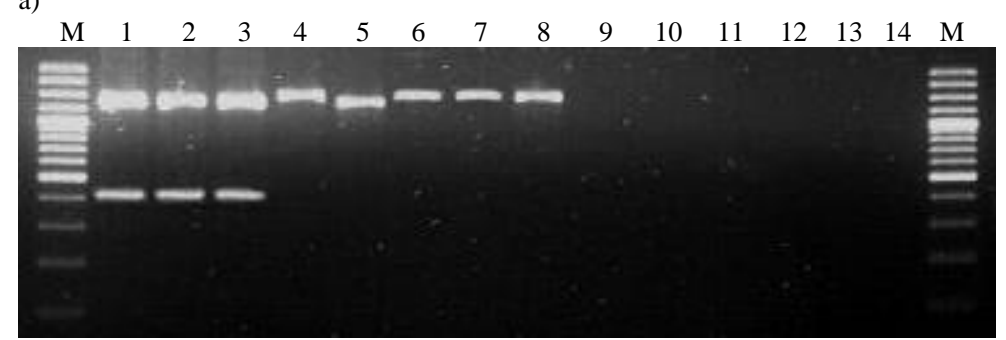

b)

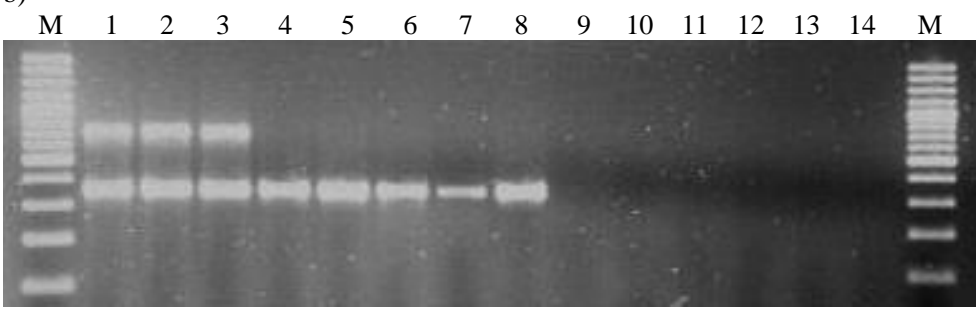

Fig. 3. Determination of the specificity of multiplex PCRs according to Chen and Knabel (2) in contaminated liver samples (a) and Doumith et al. (4) and Gouws and Liedemann (11) in contaminated brain samples (b): L. monocytogenes ATCC 7644 (1), L. monocytogenes ATCC 13932 (2), L. monocytogenes ATCC 19112 (3), L. ivanovii ATCC 19119 (4), L. innocua ATCC 33090 (5), L. grayi ATCC 19120 (6), L. welshimeri ATCC 35897 (7) and L. seeligeri (8), Bacillus cereus ATCC 11778 (9), Staphylococcus aureus ATCC 6538 (10), Escherichia coli ATCC 25922 (11), Salmonella Typhimurium ATCC 14028 (12), Klebsiella pneumoniae ATCC 13883 (13), negative control (14), and molecular weight marker (M)

As the next stage, the sensitivity of this multiplex PCR was evaluated in subsequent studies. The same sensitivity of $1.5 \times 10^{3} \mathrm{CFU} /$ reaction was found for each type of biological sample (liver, brain, and blood) with the use of either reaction mixture (Fig. 2).

To demonstrate the specificity of both multiplex PCR assays, the genetic material obtained from biological samples contaminated with three strains of L. monocytogenes, one strain of each of L. innocua, L. ivanovii, L. grayi, L. welshimeri, and L. seeligeri, and the other microorganisms Bacillus cereus, Staphylococcus aureus, Escherichia coli, Salmonella Typhimurium, and Klebsiella pneumoniae were examined (Fig. 3). The primer sets used were highly specific. An electrophoretic analysis revealed that in both multiplex PCR assays for all strains of $L$. monocytogenes two products were obtained. The strains of $L$. innocua, $L$. ivanovii, $L$. grayi, L. welshimeri, and L. seeligeri showed the presence of a fragment specific for the genus Listeria. The isolates of other microbial species failed to yield PCR products.

\section{Discussion}

PCR is an effective molecular method, which allows quick detection, amplification, and identification of small quantities of nucleic acids $(26,27)$. PCR assays provide a rapid and sensitive alternative to conventional identification based on examination of morphological, physiological, and biochemical features of L. monocytogenes (9). Virulence factors including internalins (Inl), listeriolysin O (LLO), protein p60
(Cwh A), protein ActA, phospholipase A (PlcA), and phospholipase $\mathrm{B}(\mathrm{PlcB})$ are involved in the process of pathogenesis of listeriosis $(1,13)$. These factors play a key role in the invasion and intracellular proliferation in animal tissues. The use of the PCR method enables identification a number of genes specific for L. monocytogenes species, such as hly, iap, prs, prfA, flaA, and act A $(3,8,10,13,15,17,21)$.

The PCR efficiency depends on the proper optimisation of reaction conditions. In our study, the influence of the reaction mixture and the concentration of primers for multiplex PCR assays were examined. In order to achieve the desired results a reaction mixture containing $2 \mathrm{mM}$ of $\mathrm{MgCl}_{2}$ and a Qiagen reaction mixture containing $3 \mathrm{mM}$ of $\mathrm{MgCl}_{2}$ were used. In the case of both multiplex PCR assays comparable results were obtained using the two reaction mixtures. Satisfactory results were also achieved by Douminth et al. (4), who used a magnesium ion at a concentration of $2 \mathrm{mM}$ in the reaction mixture in the case of the prs gene, and Chen and Knabel (2) who established the final concentration of magnesium ions at a level of $3 \mathrm{mM}$ in the reaction mixture for the iap and $1 \mathrm{mo} 2234$ genes.

Our findings indicated that in the multiplex PCR performed by Chen and Knabel (2) the optimal concentration of primers was different for the two reaction mixtures tested whereas the concentration was at the same level for both reaction mixtures in the case of the multiplex PCR according to Doumith et al. (4) and Gouws and Liedemann (11). Several researchers used different concentrations of primers depending on the reaction mixtures applied and conditions of PCR $(1,2,4,6,22,23)$. 
In our examinations the sensitivity of multiplex PCR according to Chen and Knabel (2) for the two reaction mixtures was at the level of $10^{4} \mathrm{CFU}$ per reaction irrespective of the type of biological sample (liver, brain, and blood). In the case of the test under Doumith et al. (4) and Gouws and Liedemann's protocols (11) the sensitivity was at a slightly higher level $\left(10^{3} \mathrm{CFU}\right.$ per reaction). Similarly Dümen et al. (6) obtained a detection limit of $10^{3} \mathrm{CFU} / 0.5 \mathrm{~mL}$ for L. monocytogenes in milk. In another report, Wernas et al. (28) also achieved a detection limit of $10^{3} \mathrm{CFU} / 0.5$ $\mathrm{g}$ in some cheeses, whereas the presence of $10^{8}$ $\mathrm{CFU} / 0.5 \mathrm{~g}$ was not detectable in others. In turn, these researchers detected at a lower limit of 1 to $10 \mathrm{CFU}$ for L. monocytogenes in pure cultures. Fitter et al. (7) also obtained a detection limit of 50 to $500 \mathrm{CFU}$ in pure cultures.

In our study, in the case of the 1mo2234 and hly genes, specific amplification products allowing the confirmation of the species as L. monocytogenes were obtained, and regarding the iap and prs genes, the presence of fragments specific for the genus Listeria was found. No specific products were found when isolates of other species of bacteria were examined. Paziak-Domańska et al. (22) and Chen and Knabel (2) also reported $100 \%$ specificity of PCR during examinations of $L$ monocytogenes and other strains of the genus Listeria.

The two multiplex PCR assays demonstrated good sensitivity and high specificity. In the next stage of studies real-time PCR for the detection of Listeria spp. and L. monocytogenes in biological samples will be applied (16). This method may also improve detection sensitivity and specificity.

Conflict of Interests Statement: The authors declare that there is no conflict of interests regarding the publication of this article.

Financial Disclosure Statement: This work was financed with the funds of the National Veterinary Research Institute in Pulawy.

Animal Rights Statement: None required.

\section{References}

1. Bubert A., Köhler S., Goebel W.: The homologous and heterologous regions within the iap gene allow genus- and species-specific identification of Listeria spp. by polymerase chain reaction. Appl Environ Microbiol 1992, 58, 2625-2632.

2. Chen Y., Knabel S.J.: Multiplex PCR for simultaneous detection of bacteria of the genus Listeria, Listeria monocytogenes, and major serotypes and epidemic clones of L. monocytogenes. Appl Environ Microbiol 2007, 73, 6299-6304.

3. Cocolin L., Manzano M., Cantoni C., Comi G.: A nested PCR method to detect Listeria monocytogenes in artificially contaminated blood specimens. Res Microbiol 1997, 148, 485-490.
4. Doumith M., Buchrieser C., Glaser P., Jacquet C., Martin P.: Differentiation of the major Listeria monocytogenes serovars by multiplex PCR. J. Clin Microbiol 2004, 42, 3819-3822.

5. Drevets D.A., Bronze M.S.: Listeria monocytogenes: epidemiology, human disease, and mechanisms of brain invasion. FEMS Immunol Med Microbiol 2008, 53, 151-165.

6. Dümen E., Baca A.Ü., Dümen E.: Comparative detection of Listeria monocytogenes in raw milk by microbiological method and PCR. Med Weter 2008, 64, 59-63.

7. Fitter S., Heuzenroeder M., Thomas C. J.: A combined PCR and selective enrichment method for rapid detection of Listeria monocytogenes. Appl Microbiol 1992, 79, 53-59.

8. Furrer B., Candrian U., Hoefelein Ch., Luethy J.: Detection and identification of Listeria monocytogenes in cooked sausage products and in milk by in vitro amplification of haemolysis gene fragments. J Appl Bacteriol 1991, 70, 372-379.

9. Gasanov U., Hughes D., Hansbro P.M.: Methods for the isolation and identification of Listeria spp. and Listeria monocytogenes: a review. FEMS Microbiol Rev 2005, 29, 851-875.

10. Goulet V., Hedberg C., Le Monnier A., de Valk H.: Increasing incidence of listeriosis in France and other European countries. Emerg Infect Dis 2008, 14, 734-740.

11. Gouws P.A., Liedemann I.: Evaluation of diagnostic PCR for the detection of Listeria monocytogenes in food products. Food Technol Biotechnol 2005, 43, 201-205.

12. Gray M.L., Killinger A.H.: Listeria monocytogenes and listeric infections. Bacteriol Rev 1966, 30, 309-382.

13. Gu Y., Liang X., Huang Z., Yang Y.: Outbreak of Listeria monocytogenes in pheasants. Poult Sci 2015, 94, 2905-2908.

14. Kaur S., Malik S.V.S., Vaidya V.M., Barbuddhe S.B.: Listeria monocytogenes in spontaneous abortions in humans and its detection by multiplex PCR. J Appl Microbiol 2007, 103, 18891896.

15. Kérouanton A., Marault M., Petit L., Grout J., Dao T. T., Brisabois A.: Evaluation of a multiplex PCR assay as an alternative method for Listeria monocytogenes serotyping. J Microbiol Methods 2010, 80, 134-137.

16. Kędrak-Jabłońska A., Budniak S., Szczawińska A., Reksa M., Krupa M., Szulowski K.: Application of SYBR Green I and TaqMan probe-based real-time PCRs for the identification of Listeria spp. and Listeria monocytogenes. Bull Vet Inst Pulawy 2015, 59, 489-494.

17. Koo K., Jaykus L.A.: Detection of Listeria monocytogenes from a model food by fluorescence resonance energy transfer-based PCR with an asymmetric fluorogenic probe set. Appl Environ Microbiol 2003, 69, 1082-1088.

18. Lecuit M.: Human listeriosis and animal models. Microb Infect 2007, 9, 1216-1225.

19. Liu D.: Preparation of Listeria monocytogenes specimens for molecular detection and identification. Inter $\mathbf{J}$ Food Microbiol 2008, 122, 229-242.

20. Low J.C., Donachie W.: A review of Listeria monocytogenes and listeriosis. Vet J 1997, 153, 9-29.

21. Negi M., Rawool D.B., Vergis J., Dhaka P., Vijay D., Mohan V., Suryavanshi R., Malik S.V.S., Kumar A., Barbuddhe S.B., Ramteke P.W.: Isolation and identification of pathogenic Listeria monocytogenes from diarrhoeal cases in human infants and young animals. Adv Anim Vet Sci 2014, 2, 5-10.

22. Paziak-Domańska B., Bogusławska E., Więckowska-Szakiel M., Kotłowski R., Różalska B., Chmiela M., Kur J., Dąbrowski W., Rudnicka W.: Evaluation of the API test, phosphatidylinositolspecific phospholipase $\mathrm{C}$ activity and PCR method in identification of Listeria monocytogenes in meat foods. FEMS Microbiol Lett 1999, 171, 209-214.

23. Rawool D.B., Malik S.V.S., Shakuntala I., Sahare A.M., Barbuddhe S.B.: Detection of multiple virulence-associated genes in Listeria monocytogenes isolated from bovine mastitis cases. Int J Food Microbiol 2007, 113, 201-207.

24. Schuchat A., Swaminathan B., Broome C.V.: Epidemiology of human listeriosis. Clin Microbiol Rev 1991, 4, 169-183. 
25. Swaminathan B., Gerner-Smidt P.: The epidemiology of human listeriosis. Microbes Infect 2007, 9, 1236-1243.

26. Van Gelder R.N.: Applications of the polymerase chain reaction to diagnosis of ophthalmic disease. Surv Ophthalmol 2001, 46, $248-258$.
27. Van Gelder R.N.: Polymerase chain reaction diagnostics for posterior segment disease. Retina 2003, 23, 445-452.

28. Wernars K., Heuvelman C.J., Chakraborty T., Notermans S.H. Use of polymerase chain reaction for direct detection of Listeria monocytogenes in soft cheese. J Appl Bacteriol 1991, 70, 121-126. 